University of Nebraska - Lincoln

DigitalCommons@University of Nebraska - Lincoln

West Central Research and Extension Center, North Platte

2011

The Role of Light and Soil Moisture in Plant Community

Resistance to Invasion by Yellow Starthistle (Centaurea solstitialis)

\author{
Stephen L. Young \\ University of Nebraska - Lincoln, steve.young@usu.edu \\ Guy B. Kyser \\ University of California, Davis \\ Jacob N. Barney \\ University of California, Davis \\ Victor P. Claassen \\ University of California, Davis \\ Joseph M. DiTomaso \\ University of California, Davis, jmditomaso@ucdavis.edu
}

Follow this and additional works at: https://digitalcommons.unl.edu/westcentresext

Part of the Agriculture Commons

Young, Stephen L.; Kyser, Guy B.; Barney, Jacob N.; Claassen, Victor P.; and DiTomaso, Joseph M., "The Role of Light and Soil Moisture in Plant Community Resistance to Invasion by Yellow Starthistle (Centaurea solstitialis)" (2011). West Central Research and Extension Center, North Platte. 11.

https://digitalcommons.unl.edu/westcentresext/11

This Article is brought to you for free and open access by the Agricultural Research Division of IANR at DigitalCommons@University of Nebraska - Lincoln. It has been accepted for inclusion in West Central Research and Extension Center, North Platte by an authorized administrator of DigitalCommons@University of Nebraska - Lincoln. 


\title{
The Role of Light and Soil Moisture in Plant Community Resistance to Invasion by Yellow Starthistle (Centaurea solstitialis)
}

\author{
Stephen L. Young, ${ }^{1}$ Guy B. Kyser, ${ }^{2}$ Jacob N. Barney, ${ }^{2}$ Victor P. Claassen, ${ }^{2}$ and Joseph M. DiTomaso ${ }^{2}$ \\ 1. University of Nebraska, West Central Research and Extension Center, 402 West Farm State Road, North Platte, NE 69101, U.S.A. \\ 2. University of California, Plant Sciences, One Shields Avenue, Davis, CA 95616, U.S.A. \\ Corresponding author - J. M. DiTomaso, email jmditomaso@ucdavis.edu
}

\begin{abstract}
To resist establishment by an invasive plant, a community may require one or more species functionally similar to the invader in their resource acquisition pattern. In this study, communities consisting of native winter annual forbs, non-native annual grasses, native perennials, or a combination of the two native communities were established with and without Centaurea solstitialis to determine the effect of soil moisture and light availability on plant community invasion resistance. The annual plant communities were unable to resist invasion by $C$. solstitialis. In the native winter annual forb community, senescence in late spring increased light penetration $(>75 \%)$ to the soil surface, allowing seeded $C$. solstitialis to quickly establish and dominate the plots. In addition, native annual forbs utilized only shallow soil moisture, whereas C. solstitialis used shallow and deep soil moisture. In communities containing native perennials, only Elymus glaucus established well and eventually dominated the plots. During the first 2 years of establishment, water use pattern of perennial communities was similar to native annual forbs and resistance to invasion was associated with reduced light availability during the critical stages of C. solstitialis establishment. In later years, however, water use pattern of perennial grass communities was similar or greater than C. solstitialis-dominated plots. These results show that Central Valley grasslands that include E. glaucus resist C. solstitialis invasion by a combination of light suppression and soil water competition. Spatiotemporal resource utilization patterns, and not just functional similarity, should be considered when developing restoration strategies to resist invasion by many non-native species.
\end{abstract}

Keywords: Elymus glaucus, functional similarity, grassland, invasive plant, light availability, native perennial grasses, soil moisture

\section{Introduction}

Successful establishment of an introduced species has been postulated to be influenced by species richness within the ecosystem (reviewed in Lonsdale 1999). Elton (1958) first hypothesized that exotic species can more easily invade areas of low species diversity; later researchers have suggested that species-rich communities exploit limiting resources more completely, and thus are less invasible (Robinson et al. 1995; Tilman 1997; Levine 2000; Dukes 2001; Hector et al. 2001). More recent evidence indicates that invasion of a particular species into a community is closely related to resource use dynamics and life-history traits of the species (Seabloom et al. 2003; Suding et al. 2003; Zavaleta \& Hulvey 2007). For example, we previously reported (Young et al. 2009, 2010) that an established plant community with species functionally similar to the invader Centaurea solstitialis is more likely to resist invasion and remain intact. In particular, communities dominated by the native perennial grass Elymus glaucus resisted invasion by C. solstitialis. We found that similarity in season of growth was aiding this resistance and speculate that timing of light use and soil moisture use patterns were additional contributing mechanisms.

Variability in rainfall pattern for the Central Valley of California makes efficient water use critical for the establishment and survival of native species. Several studies have addressed the role that invasive plants play in limiting water availability to natives (Gordon et al. 1989; Holmes \& Rice 1996; Hamilton et al. 1999; Dukes 2002; Thomsen et al. 2006). For example, many non-native annual species gain a competitive advantage over native perennial grasses by quickly developing roots in the upper soil profile and depleting available water before slower developing natives can establish (Enloe \& DiTomaso 2004). The most widespread non-native invasive annual in California grasslands is C. solstitialis, which infests over 6 million ha (Pitcairn et al. 2006). It is often the target of restoration programs due to its exclusion of native spe- 
Table 1. Species compositions in four plant communities used in this study to assess their resistance to Centaurea solstitialis invasion.

\begin{tabular}{llll}
\hline & & Species & \\
\hline AG & AF & NP & FP \\
\hline Avena fatua & Gilia tricolor & Elymus glaucus & Lasthenia glabrata \\
Aegilops triuncialis & Lasthenia glabrata & Elymus trachycaulus & Layia platyglossa \\
Bromus hordeaceus & Layia platyglossa & Leymus triticoides & Lupinus bicolor \\
Hordeum murinum & Lupinus bicolor & Nassella pulchra & Elymus glaucus \\
Lolium multiflorum & Nemophila menziesii & Grindelia camporum & Nassella pulchra \\
Taeniatherum caput-medusae & Trifolium willdenovii & Lotus purshianus* & Grindelia camporum \\
\hline
\end{tabular}

*Annual species

cies, and excessive use of limited soil moisture (Enloe \& DiTomaso 2004). For example, under normal precipitation conditions, Gerlach and Rice (1996) found that deep soil water potentials $(1.25 \mathrm{~m})$ in late summer were near field capacity $(-0.3 \mathrm{MPa})$ for a grassland dominated by annual grasses $(\mathrm{AG})$, but were much dryer $(-3.5 \mathrm{MPa})$ for a grassland infested with $C$. solstitialis.

Light availability can also impact establishment of invasive species in native plant communities (Seabloom et al. 2003; Reinhart et al. 2006; Thomsen \& D'Antonio 2007). DiTomaso et al. (2003) experimentally reduced light reaching $C$. solstitialis plants at the rosette stage by $92 \%$ and found root growth rates were dramatically reduced compared to plants growing in full sunlight. Aboveground growth of $C$. solstitialis is also very susceptible to light suppression; a 50\% reduction in sunlight was shown to reduce aboveground biomass by $75 \%$ (Roché et al. 1994). Thus, by reducing light penetration to the soil surface, invasion of non-native species such as $C$. solstitialis may be suppressed in grassland communities, even when other resources such as soil water and nutrients are non-limiting (Corbin \& D' Antonio 2004).

In a previous study, we showed that communities containing functionally similar species, regarding life-history traits, were resistant to $C$. solstitialis invasion (Young et al. 2009, 2010). However, the underlying mechanisms were unknown. Therefore, in this study we examined the spatiotemporal patterns of soil moisture use and light capture as potential mechanisms driving this resistance, particularly in communities dominated by E. glaucus. We hypothesized that species with functional complementarity in light and water usage to $C$. solstitialis would drive community resistance to invasion of C. solstitialis in California grasslands.

\section{Methods}

\section{Establishment of Plant Communities}

The study was conducted at the University of California-Davis $\left(38^{\circ} 33^{\prime} \mathrm{N}, 121^{\circ} 48^{\prime} \mathrm{W}, 18 \mathrm{~m}\right.$ elevation), California, where mean annual precipitation is approximately $480 \mathrm{~mm}$; see Young et al. (2009) for site details. Seasonal precipitation totals for 2001-2002 through 2004-2005 were $338,510,397$, and $516 \mathrm{~mm}$, respectively, which ranged between 70 and $108 \%$ of normal.
The experimental communities comprised annual or perennial forbs and grasses, with their functional group classification based on the seasonality of resource use according to Hickman (1993) and DiTomaso and Healy (2007). All species chosen were known to occur in grassland ecosystems near the study site (Table 1). The natives are considered the most suitable for restoration programs in northern California and surrounding regions (Bugg et al. 1997) and the non-native AG are common components of the Central Valley grasslands in California (Young et al. 2009).

Communities were planted in a randomized complete block design with five replications in $4 \times 4$-m plots with 2-m wide alleys between plots. Plant communities of six species each (Table 1) were established in fall 2000 (2001 for AG plots) and consisted of native winter annuals (annual forbs $=\mathrm{AF}$ ), non-native winter annual grasses (annual grasses $=A G$ ), native summer perennials plus one summer annual (native perennials $=\mathrm{NP}$ ), and a combination of AF and NP species (annual forbs and perennials $=\mathrm{FP})$.

In fall 2001 (2002 for AG), Centaurea solstitialis was overseeded at 1,000 seeds $/ \mathrm{m}^{2}(2 \mathrm{~kg} /$ ha; see Young et al. 2009 for details) in half (five plots each) the plots of each plant community (hereafter labeled with + CS), and also planted as a monoculture in five separate plots (CS). Bareground control plots (five replicates) were used for comparing soil water to the experimental plant communities. After 3 years of establishment without disturbance, all plots were mowed in November 2004 and 2005 to simulate fall grazing. This was not a treatment, but was a simulation of actual practices following revegetation, with the goal of removing thatch and maintaining healthy rangeland. Heady (1988) reported that late-season grazing is common in northern California rangelands.

\section{Cover}

Individual species cover measurements were taken in spring (April) and summer (July) from 2002 to 2005. Although C. solstitialis reaches peak cover in summer, spring measurements account for the peak cover of other planted species, and also rosette cover of C. solstitialis. This spring timing also correlates with peak light capture and soil moisture use (Young et al. 2010). Measurements were conducted within permanent $0.5 \times$ 
0.5-m subplots in each corner of the plot (four subplots per plot approximately $0.25 \mathrm{~m}$ from the plot edges) and averaged for each plot. Within a subplot canopy cover of each plant species, thatch and bareground were visually estimated to within $1 \%$ when values were $10 \%$ or less, or to the nearest $5 \%$ when values were above $10 \%$, and summed to $100 \%$.

\section{Soil Water Content}

Soil water content was collected in June 2003 and 2005. From previous work (Young et al. 2010), we showed that maximum differences in soil moisture depletion compared to bareground plots occurred in June. We used a neutron probe (CPN Corporation, Pacheco, CA, U.S.A.) in 2003 and access tubes were installed in the center of each plot to $2 \mathrm{~m}$ in depth. Soil moisture measurements were recorded at 30-cm intervals from 30 to $180 \mathrm{~cm}$ in depth. Samples were analyzed for soil gravimetric water content and converted to volumetric water content.

\section{Light Transmission}

Light transmission in each plant community was measured in February, April, May, July, and September 2002 during the first year of C. solstitialis establishment in seeded plots, except AG plots which were not established yet. In the years following C. solstitialis addition, light penetration to the soil surface (collected in spring and summer in 2003 through 2005) was not significantly different among communities and never exceeded 10\% (data not shown). The reduced light availability was caused by either $C$. solstitialis in the annual communities or Elymus glaucus in the perennial communities. Photosynthetically active radiation (PAR) was measured using a ceptometer (Decagon Devices, Inc., Pullman, WA, U.S.A.) with an $80-\mathrm{cm}$ sensor bar, which was inserted under the canopy of each plot at the soil surface between $10 \mathrm{am}$ and $2 \mathrm{pm}$. Eight readings were averaged for each plot, and full sunlight PAR values were recorded above the canopy following each soil surface measurement. Data are presented as percent light transmission compared to full sunlight.

\section{Statistical Analysis}

Centaurea solstitialis cover was compared among +CS communities in each year (2002-2005) using analysis of variance (ANOVA), and means $(n=5)$ were separated using Tukey's Studentized test at $p<0.05$. Statistical analyses for cover and light were performed using SAS (2002), with plant community as the independent variable.

Soil moisture depletion was compared among communities using multiple response permutation procedures (MRPPs), a nonparametric technique designed to test the hypothesis of no difference among a priori groups (Mielke \& Berry 1982). MRPP was performed in PC-ORD 5.0 (2006, MJM Software Design, Gleneden Beach, OR, U.S.A.). $T$ tests were used for pair-wise comparisons of moisture depletion in the deep soil (150 and $180 \mathrm{~cm}$ combined).

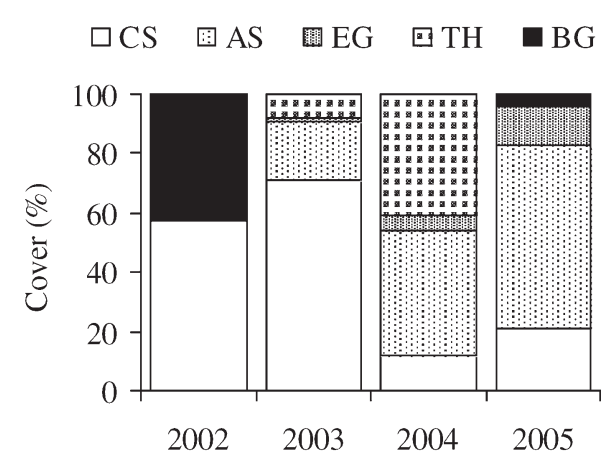

Figure 1. Spring cover in Centaurea solstitialis monoculture plots (CS). CS, C. solstitialis; AS, resident non-native winter annual forb and grass species; EG, E. glaucus; TH, thatch; and BG, bareground.

\section{Results}

\section{Plant Cover}

Centaurea solstitialis Monocultures. In the Centaurea solstitialis monoculture plots (CS), spring cover reached a peak $(71 \%$ cover) in the second year (2003), but declined to $15-20 \%$ in 2004 and 2005 as thatch and other annual weeds increased (Figure 1). During this period, Elymus glaucus went from being absent to $15 \%$ in the $C$. solstitialis monocultures.

Annual Communities. Cover of native winter annual forbs (AF and $\mathrm{AF}+\mathrm{CS}$ ) was highest in the first spring after seeding (2002), but declined subsequently (Figure 2a $\& 2 b)$. By 2005, small spring flushes of two native forbs (Nemophila menziesii and Lasthenia glabrata) remained in only a few plots (data not shown). The decrease in native winter annuals coincided with an increase in C. solstitialis and other resident non-native winter annual species in the AF and AF+CS plots (Figure 2a \& 2b). Although spring cover of $C$. solstitialis in the $\mathrm{AF}+\mathrm{CS}$ plots was low (10\%) in the first year after seeding, by the second season after overseeding (2003), spring cover of $C$. solstitialis had increased to $46 \%$ (Figure $2 \mathrm{~b}$ ). Cover of C. solstitialis declined in the AF+CS plots in 2004 and 2005 (Figure 2b), with spring cover values reaching 6\% in 2004 and $2 \%$ in 2005 . The reduction in C. solstitialis in AF+CS plots in 2004 and 2005 coincided with an increase in resident non-native winter annuals, particularly Lactuca serriola (prickly lettuce), Vicia villosa (hairy vetch), Brassica rapa (birdsrape mustard), Sinapis arvensis (wild mustard), Bromus diandrus (ripgut brome), and Lolium multiflorum (Italian ryegrass).

In the annual grass community with $C$. solstitialis added $(\mathrm{AG}+\mathrm{CS}), \mathrm{C}$. solstitialis was not detected in the spring following seeding (2003). In 2004, C. solstitialis cover was not only high in AG+CS plots $(60 \%)$, but had invaded AG plots to the same level from surrounding seeded plots (Figure 2c \& 2d). Centaurea solstitialis remained dominant the following year (2005) in both AG and AG+CS plots. In 2004 and 2005, C. solstitialis cover was always greater in the AG+CS community as compared with all other +CS communities (Table 2). 


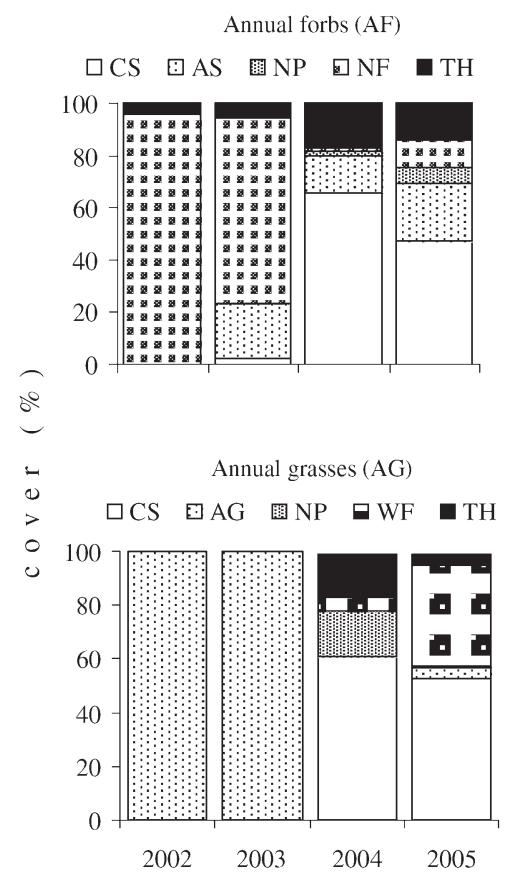

(a)

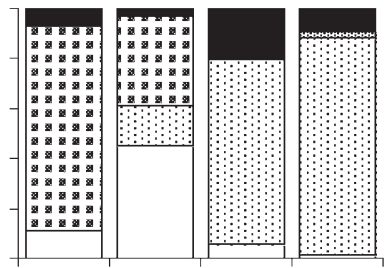

(b)
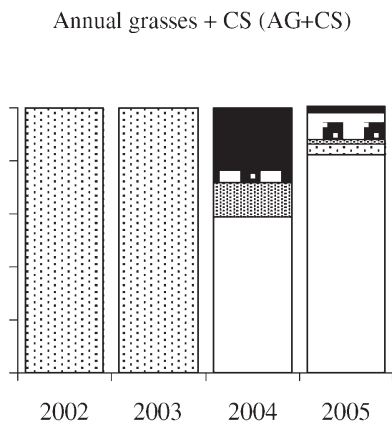

(c)

(d)

Figure 2. Spring cover in the native AF community without (a) and with (b) Centaurea solstitialis (AF+CS) and non-native AG community without (c) and with (d) C. solstitialis (AG+CS). CS, C. solstitialis; AS, resident non-native winter annual species (panels a and b); AG, planted non-native annual grasses (panels c and d); NP, native perennial forbs and grasses; NF, native winter annual forbs; WF, non-native annual forbs (panels c and d); and TH, thatch. Top legend applies to panels (a) and (b), while bottom legend applies to panels (c) and (d).

Perennial Communities. In the native perennial plots (NP) (Figure 3a \& 3b), E. glaucus was the dominant species in every year of the study, while the other perennials were sporadic in their occurrence (data not shown). In the mixed native annual and perennial plots (FP), both native annual forbs and E. glaucus were well established by spring of 2002 (Figure 3c \& 3d). However, in the following year few native annual forbs remained and the dominant species in these plots was also E. glaucus (data not shown). The native perennial grasses Elymus trachycaulus, Nassella pulchra, and Leymus triticoides and the native forbs Lotus purshianus, Layia platyglossa, and Lupinus bicolor were sparse or absent in both NP and FP communities by 2003. Cover of C. solstitialis was minor $(7 \%)$ in the first year after seeding in the FP+CS and NP+CS communities (Figure $3 \mathrm{~b} \& 3 \mathrm{~d}$ ), and the plots were dominated by E. glaucus. The year following mowing (2005), C. solstitialis spring cover remained very low in both perennial communities.

\section{Light}

All winter annual communities (AF, AF+CS, and CS) had approximately $75 \%$ light transmission to the soil surface in February 2002 (Figure 4). The mixed community with native annuals and perennials (FP and $\mathrm{FP}+\mathrm{CS}$ ) also had high light transmission (approximately 60\%), although it was significantly lower than the annual communities (Figure 4). In contrast, the native perennial community (NP) had only $24(\mathrm{NP})$ and $30 \%(\mathrm{NP}+\mathrm{CS})$ light transmission in February. By spring (April, May), light at the soil surface in all native plant communities

Table 2. Linear contrasts using Tukey's Studentized test ( $p$ values) of Centaurea solstitialis cover between each mixed plant community (AG, annual grasses; AF, annual forbs; NP, native perennials; FP, annual forbs and perennials) overseeded with $C$. solstitialis.

\begin{tabular}{|c|c|c|c|c|c|c|c|c|}
\hline Treatment Contrast & $\begin{array}{l}2002 \\
\text { Spring } \\
\end{array}$ & Summer & $\begin{array}{l}2003 \\
\text { Spring } \\
\end{array}$ & Summer & $\begin{array}{l}2004 \\
\text { Spring }\end{array}$ & Summer & $\begin{array}{l}\text { 2005 } \\
\text { Spring }\end{array}$ & Summer \\
\hline $\mathrm{AG}+\mathrm{CS}$ vs. $\mathrm{AF}+\mathrm{CS}$ & $\mathrm{N} / \mathrm{A}$ & $\mathrm{N} / \mathrm{A}$ & $\mathrm{N} / \mathrm{A}$ & $<0.0001$ & $\leq 0.0001$ & 0.20 & $\leq 0.0001$ & $\leq 0.0001$ \\
\hline $\mathrm{AG}+\mathrm{CS}$ vs. $\mathrm{NP}+\mathrm{CS}$ & $\mathrm{N} / \mathrm{A}$ & $\mathrm{N} / \mathrm{A}$ & $\mathrm{N} / \mathrm{A}$ & $\underline{0.03}$ & $\overline{<0.0001}$ & 0.029 & $\overline{<0.0001}$ & $\overline{<0.0001}$ \\
\hline $\mathrm{AF}+\mathrm{CS}$ vs. NP+CS & 0.38 & $\underline{0.0014}$ & $<0.0001$ & $<\overline{0.0001}$ & 0.50 & $\overline{0.28}$ & 0.038 & 0.0005 \\
\hline $\mathrm{AF}+\mathrm{CS}$ vs. $\mathrm{FP}+\mathrm{CS}$ & 0.50 & $\overline{0.0099}$ & $\overline{<0.0001}$ & $\overline{<0.0001}$ & 0.38 & 0.24 & 0.82 & 0.60 \\
\hline $\mathrm{NP}+\mathrm{CS}$ vs. $\mathrm{FP}+\mathrm{CS}$ & 0.83 & 0.20 & 1.0 & 0.80 & 0.83 & 0.92 & $\underline{0.025}$ & $\underline{0.0002}$ \\
\hline
\end{tabular}

N/A, data not available.

Bolded values are significant at $p<0.05$. The GLM method in SAS was used to determine statistical significance $(n=5)$. In each row, underlined bold $p$ values indicate higher $C$. solstitialis cover in first community listed under treatment contrast. 


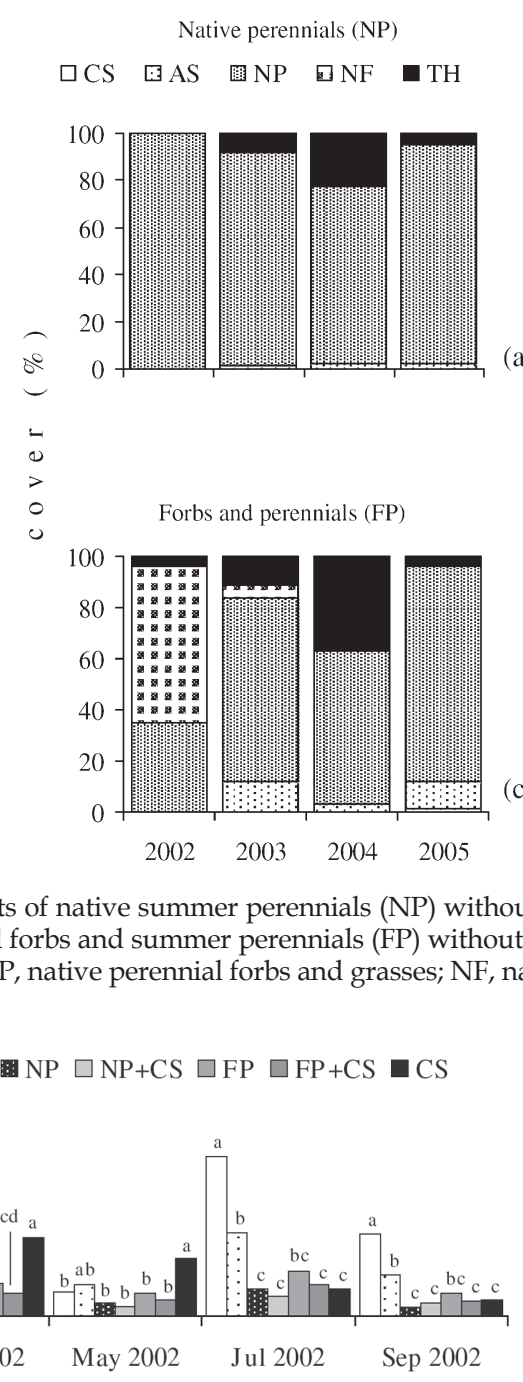

Figure 4. Percentage light transmission to the soil surface during winter (February), spring (April and May), summer (July), and fall (September) of 2002. Plant communities include AF, native annual forbs; $\mathrm{AF}+\mathrm{CS}$, Centaurea solstitialis added to $\mathrm{AF} ; \mathrm{NP}$, native summer perennials; NP+CS, C. solstitialis added to NP; FP, combination of native forbs and perennials; FP+CS, C. solstitialis added to FP; and CS, C. solstitialis alone. For each timing, statistical differences between treatments $(n=$ $5)$ denoted by letter(s) $(p<0.05)$ using Tukey's Studentized $t$ test.

dropped to less than $18 \%$ of full sunlight (Figure 4). Throughout 2002, NP communities always had the lowest light transmission of all plant communities, including the CS monoculture. reached the soil surface in AF plots compared with $\mathrm{AF}+\mathrm{CS}$ plots (Figure 4). Following senescence of native winter annuals in early June, light transmission increased to $73 \%$ in AF plots, compared to $38 \%$ in the $\mathrm{AF}+\mathrm{CS}$ community. By September, light transmission remained higher in AF plots (38\%) compared to AF+CS plots $(19 \%)$. By contrast, light transmission in the perennial communities never exceeded $20 \%$ in late season.

Between February and September, light transmission in CS monoculture plots declined from nearly $70 \%$
Native perennials + CS $(\mathrm{NP}+\mathrm{CS})$

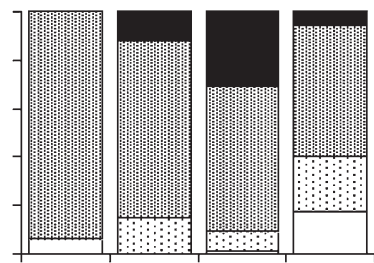

(b)

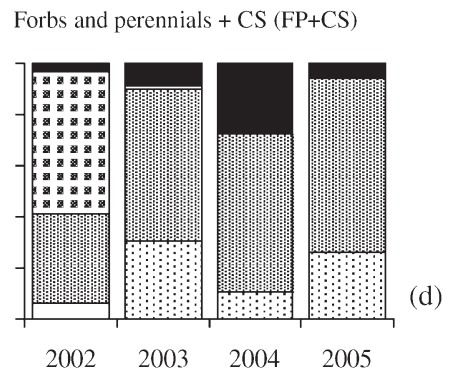

Figure 3. Spring cover in plots of native summer perennials (NP) without (a) and with (b) Centaurea solstitialis (NP+CS). Lower panels are cover of a (d) C. solstitialis (FP+CS). CS, C. solstitialis; AS, resident non-na-

In both July and September, significantly more light

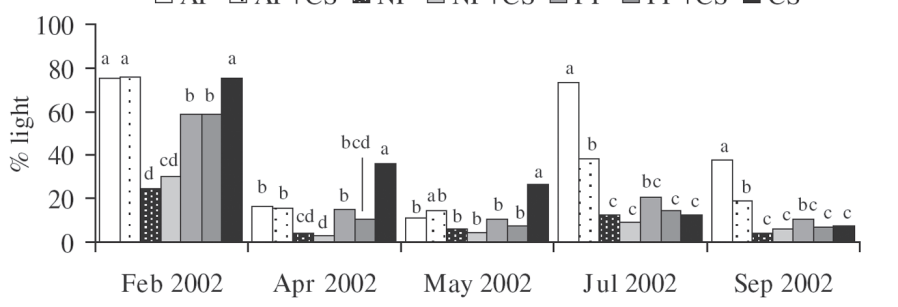

in February to less than $10 \%$ in September, owing to aboveground growth of $C$. solstitialis through spring and summer.

\section{Soil Water Content}

Precipitation patterns in 2003 and 2005 were similar, totaling 106 and $108 \%$ of normal, respectively.

In 2003, total water depletion tended to be greater in $\mathrm{CS}$ and $\mathrm{AF}+\mathrm{CS}$ plots compared with AF plots, significantly so in the deeper soil (150 and $180 \mathrm{~cm}$ ) (Figure 5a; Table 3). This increased water depletion corresponded to C. solstitialis cover values of 59 and $67 \%$ in CS and $\mathrm{AF}+\mathrm{CS}$ plots (Figure 2d), respectively, compared to $15 \%$ cover in AF plots (Figure 2c). In 2005, the AF community was dominated by C. solstitialis ( $50 \%$ cover) and had the greatest total water depletion (Figure 5b; Table 3).

In both the native perennial (NP) and the mixed native (FP) communities, there was almost no C. solstitialis in either the seeded or unseeded plots in 2003 (Figure 5c \& 5e). These plots consisted primarily of E. glaucus. As a result, the water depletion patterns were similar among the both native plant communities with and without the addition of C. solstitialis seeds, and much of the water depletion occurred in the shallow soil (Figure $5 c$ \& $5 e$ ). In contrast, CS plots depleted significantly more water in the deeper soil (Table 3).

\section{Discussion}

AG and native annual forb communities are susceptible to invasion because of their inability to suppress light availability and non-overlapping water use pattern 
Table 3. Probability values for MRPPs and $t$ test comparisons of soil moisture profiles under experimental communities.

\begin{tabular}{|c|c|c|c|c|c|c|c|c|c|}
\hline \multirow[b]{2}{*}{ Year } & \multicolumn{3}{|c|}{$\mathrm{AF}, \mathrm{AF}+\mathrm{CS}, \mathrm{CS}$} & \multicolumn{3}{|c|}{$\mathrm{NP}, \mathrm{NP}+\mathrm{CS}, \mathrm{CS}$} & \multicolumn{3}{|c|}{$\mathrm{FP}, \mathrm{FP}+\mathrm{CS}, \mathrm{CS}$} \\
\hline & Communities & MRPP & $\begin{array}{l}\text { T Test for } \\
\text { Deep Soil }\end{array}$ & Communities & MRPP & $\begin{array}{l}\text { T Test for } \\
\text { Deep Soil }\end{array}$ & Communities & MRPP & $\begin{array}{l}\text { T Test for } \\
\text { Deep Soil }\end{array}$ \\
\hline & Overall & 0.28 & & Overall & $0.029^{* *}$ & & Overall & 0.15 & \\
\hline 2003 & $\begin{array}{l}\text { AF vs. } A F+C S \\
A F \text { vs. } C S \\
A F+C S \text { vs. } C S\end{array}$ & $\begin{array}{l}0.16 \\
0.078^{*} \\
1.00 \\
\end{array}$ & $\begin{array}{l}0.025^{* *} \\
0.022^{* *} \\
0.59\end{array}$ & $\begin{array}{l}\text { NP vs. NP+CS } \\
\text { NP vs. CS } \\
\text { NP+CS vs. CS }\end{array}$ & $\begin{array}{l}0.16 \\
0.033^{* *} \\
0.041^{* *}\end{array}$ & $\begin{array}{l}0.63 \\
0.012^{* *} \\
0.027^{* *}\end{array}$ & $\begin{array}{l}\text { FP vs. FP+CS } \\
\text { FP vs. CS } \\
\text { FP+CS vs. CS }\end{array}$ & $\begin{array}{l}0.96 \\
0.079^{*} \\
0.071^{*}\end{array}$ & $\begin{array}{l}0.43 \\
0.0080^{* *} \\
0.016^{* *}\end{array}$ \\
\hline 2005 & $\begin{array}{l}\text { AF vs. } A F+C S \\
A F \text { vs. } C S \\
A F+C S \text { vs. CS }\end{array}$ & $\begin{array}{l}0.0063^{* *} \\
0.022^{* *} \\
0.47\end{array}$ & $\begin{array}{l}0.00057^{* *} \\
0.11 \\
0.21\end{array}$ & $\begin{array}{l}\text { NP vs. NP+CS } \\
\text { NP vs. CS } \\
\text { NP+CS vs. CS }\end{array}$ & $\begin{array}{l}0.53 \\
0.72 \\
0.089^{*}\end{array}$ & $\begin{array}{l}0.71 \\
0.44 \\
0.25\end{array}$ & $\begin{array}{l}\text { FP vs. FP+CS } \\
\text { FP vs. CS } \\
\text { FP+CS vs. CS }\end{array}$ & $\begin{array}{l}0.96 \\
0.81 \\
0.86\end{array}$ & $\begin{array}{l}0.79 \\
0.93 \\
0.90\end{array}$ \\
\hline
\end{tabular}

"Deep soil" represents sum of moisture values at 150 and $180 \mathrm{~cm}$.

${ }^{* *} p<0.05$ and ${ }^{*} p<0.1$ are indicated.

during the critical growth phases of Centaurea solstitialis. In contrast to the annual communities, we showed that established native perennial grass communities have light-suppressive capabilities and soil water use patterns that at least partially account for the resistance to C. solstitialis invasion.

Light transmission to the soil surface was highest in native annual plots, compared to other communities. The native annual forbs complete their life cycle and begin to senesce by late spring. At this time (May through July), C. solstitialis is in the bolting and spiny stages, where growth is rapid (DiTomaso et al. 2003) and plants are most sensitive to light suppression (Roché et al. 1994). Plant communities composed of native perennial species, particularly Elymus glaucus, reduced light transmission during this critical period. For the same reason, C. solstitialis does not occur in shaded areas under tree or shrub canopies (Gerlach \& Rice 2003; DiTomaso et al. 2007).

In addition, thatch cover increased in the C. solstitialis monocultures from 2003 to 2004, reducing light transmission to the soil surface, which coincided with reduced C. solstitialis cover. Thus, C. solstitialis may suppress its own population when the thatch layer is allowed to build up in the absence of disturbances such as grazing, mowing, tillage, or burning.

While light suppression at critical stages of C. solstitialis development may be a primary driver invasion resistance, soil moisture use patterns also play an important role (Gerlach \& Rice 2003). Similarity in water use pattern is important to the competitive ability of restoration species (E. glaucus in this study), and appears to be a factor in resistance to $C$. solstitialis following establishment of the desired plant community. In support of this, water depletion patterns in perennial and mixed perennial (NP and FP) plots in 2003 were similar to AF plots, but far less than plots dominated by C. solstitialis. However, by 2005, water depletion in the perennial communities was similar, or greater, compared to the C. solstitialis-dominated plots. Furthermore, the perennial communities depleted considerably more deep soil water $(150-180 \mathrm{~cm})$ in 2005 compared to 2003, suggesting that the perennial com- munities had not yet established a deep root system by spring of 2003. This supports our previous work (Young et al. 2009) that reported perennial grasses, particularly $E$. glaucus, to be functionally similar to $C$. solstitialis with respect to their water use patterns.

Our results, as well as that of others (Enloe \& DiTomaso 2004; Gerlach 2004), show that C. solstitialis is able to exploit moisture deeper in the soil profile compared to more shallow-rooted annual species. In grasslands consisting primarily of winter annuals, C. solstitialis can occupy an available niche with little competition from existing species in the community. Thus, similarity in water use patterns plays an important role in competitive resistance to $C$. solstitialis invasion following the establishment of a desirable plant community.

We have observed population fluctuations of C. solstitialis among years, with periods of high densities lasting a couple of years followed by periods of very low densities within the same area. This pattern occurred in $\mathrm{AF}+\mathrm{CS}$ and C. solstitialis monoculture plots, as C. solstitialis populations peaked early in the study. In the AG, $\mathrm{AG}+\mathrm{CS}$, and AF communities, the C. solstitialis population peaked the last 2 years of the study, preceding a possible population decline. Gerlach (2004) and Enloe et al. (2005) reported that precipitation patterns correlate with $C$. solstitialis population densities, with drought years appearing to result in low densities. However, we observed population fluctuations despite having only minor precipitation variation throughout the study. In this study, we speculate that the decline in C. solstitialis populations was due to (1) inability to recharge deep soil moisture (DiTomaso et al. 2003; Young et al. 2010); (2) light suppression via thatch buildup; or (3) competition from other annual non-native species.

\section{Conclusion}

Communities with species functionally similar to an invader are more likely to compete for available resources with invasive species (Vitousek \& Hooper 1997; Fargione et al. 2007; Zavaleta \& Hulvey 2007; Young et al. 2009). In our case, light and soil moisture use pat- 


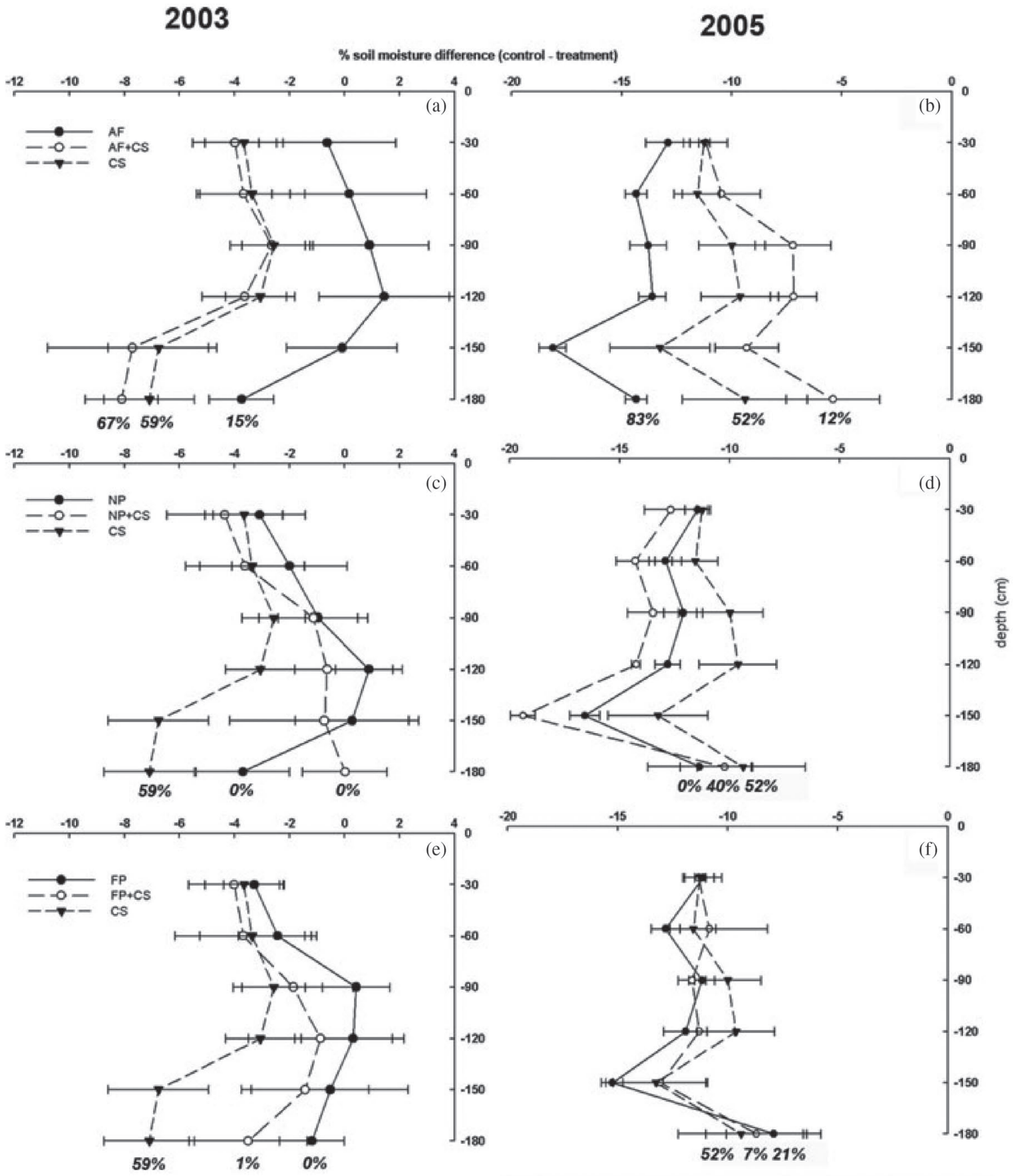

Figure 5. Soil moisture use profiles for native AF, NP, and the combination of native forbs and perennials (FP) relative to bareground control plots for 2003 (panels a, c, and e) and 2005 (panels b, d, and f). End-of-season (June) water depletion is presented as the difference in soil moisture between each plant community versus bareground controls, in volumetric soil water content at each depth. Negative numbers indicate water use in treatments are greater than bareground control plots (percent soil moisture in bareground plots minus percent moisture in plant community plots). Data points represent means $(n=5) \pm$ SE. Percentages at bottom of each line represent summer (July) Centaurea solstitialis cover in each community.

terns appear to be the drivers behind Centaurea solstitialis resistance, and should be considered when choosing restoration species. Under Central Valley conditions, Elymus glaucus was shown to be the most successful perennial grass species for a restoration program. In addition, it was the only native species that dispersed and colonized plots in which it was not seeded. Although the results of this study are directly relevant to many grasslands systems throughout California, they are also applicable to invaded grasslands of semiarid regions throughout the world. In all these systems, identifying desirable species that are functionally similar, with respect to the critical characteristics suppressing invasion, is a key requirement for successful restoration. 


\section{Implications for Practice}

- In a Mediterranean-type climate, the native perennial grass Elymus glaucus was most successful in its establishment, spread, and resistance to Centaurea solstitialis invasion. Resistance to $C$. solstitialis invasion by E. glaucus was primarily due to light suppression during the critical period in C. solstitialis development.

- While functional similarity in water depletion patterns between restoration species and $C$. solstitialis plays a role in invasion resistance, it appears to be of lesser importance compared to light suppression.

-When designing a restoration program to resist a specific invasive species, or suite of similar species, the life history/niche vulnerabilities of the invader (e.g. light) should be exploited when selecting desirable species.

\section{Literature Cited}

Bugg, R. L., C. S. Brown, and J. H. Anderson. 1997. Restoring native perennial grasses to rural roadsides of the Sacramento Valley of California: Establishment and evaluation. Restoration Ecology $5: 214-225$.

Corbin, J. D., and C. M. D'Antonio. 2004. Competition between native perennial and exotic annual grasses: Implications for an historical invasion. Ecology 85:1273-1283.

DiTomaso, J. M., and E. A. Healy. 2007. Weeds of California and Other Western States. University of California, Department of Agriculture and Natural Resources, Oakland, Publ. \#3488.

DiTomaso, J. M., G. B. Kyser, and C. B. Pirosko. 2003. Effect of light and density on yellow starthistle (Centaurea solstitialis) root growth and soil moisture use. Weed Science 51:334-341.

DiTomaso, J. M., M. J. Pitcairn, and S. F. Enloe. 2007. Pages 281-296 in R. Stromberg, J. D. Corbin, and C. M. D'Antonio, editors. California Grasslands. Ecology and Management. University of California Press, Berkeley.

Dukes, J. S. 2001. Biodiversity and invasibility in grassland microcosms. Oecologia 126:563-568.

Dukes, J. S. 2002. Species composition and diversity affect grassland susceptibility and response to invasion. Ecological Applications 12:602-617.

Elton, C. S. 1958. The Ecology of Invasions by Animals and Plants. Methuen, London, United Kingdom.

Enloe, S. F., and J. M. DiTomaso. 2004. Soil water dynamics differ among rangeland plant communities dominated by yellow starthistle (Centaurea solstitialis) annual grasses or perennial grasses. Weed Science 52:929-935.

Enloe, S. F., J. M. DiTomaso, S. Orloff, and D. Drake. 2005. Perennial grass establishment integrated with clopyralid treatment for yellow starthistle management on annual range. Weed Technology 19:94-101.

Fargione, J., D. Tilman, R. Dybzinski, J. H. Ris Lambers, C. Clark, W. S. Harpole, J. M. Knops, P. B. Reich, and M. Loreau. 2007. From selection to complementarity: Shifts in the causes of biodiversity-productivity

relationships in a long-term biodiversity experiment. Proceedings of the Royal Society Biological Sciences, Series B 274:871-876.

Gerlach, J. D. 2004. The impacts of serial land-use changes and biological invasions on soil water resources in California, USA. Journal of Arid Environments 57:365-379.

Gerlach, J. D., and K. J. Rice. 1996. Centaurea solstitialis threatens California's ecosystems. Bulletin of the Ecological Society of America 77:160.

Gerlach, J. D., and K. J. Rice. 2003. Testing life history correlates of invasiveness using congeneric plant species. Ecological Applications 13:167-179.
Gordon, D. R., J. M. Welker, J. W. Menke, and K. J. Rice. 1989. Competition for soil water between annual plants and blue oak (Quercus douglasii ) seedlings. Oecologia 79:533-541.

Hamilton, J. G., C. Holzapfel, and B. E. Marshall. 1999. Coexistence and interference between a native perennial grass and non-native annual grasses in California. Oecologia 121:518-526.

Heady, H. A. 1988. Valley grassland. Pages 491-512 in M. G. Barbour and J. Major, editors. Terrestrial Vegetation of California. Wiley Interscience, New York.

Hector, A., K. Dobson, A. Mins, E. Bazeley-White, and J. H. Lawton. 2001. Community diversity and invasion resistance: an experimental test in a grassland ecosystem and a review of comparable studies. Ecological Research 16:819-831.

Hickman, J.C. 1993. The Jepson Manual: Higher plants of California. University of California Press, Berkeley.

Holmes, T. H., and K. J. Rice. 1996. Patterns of growth and soil-water utilization in some exotic annuals and native perennial bunchgrasses of California. Annals of Botany 78:233-243.

Levine, J. M. 2000. Species diversity and biological invasions: Relating local process to community pattern. Science 288:852-854.

Lonsdale, W. M. 1999. Global patterns of plant invasions and the concept of invasibility. Ecology 80:1522-1536.

Mielke, P. W. Jr, and K. J. Berry. 1982. An extended class of permutation techniques for matched pairs. Communications in StatisticsTheory and Methods 11:1197-1207.

Pitcairn, M. J., S. Schoenig, R. Yacoub, and J. Gendron. 2006. Yellow starthistle continues its spread in California. California Agriculture 60:83-90.

Reinhart, K. O., J. Gurner, R. Tirado, and R. M. Callaway. 2006. Invasion through quantitative effects: Intense shading drives native decline and invasive success. Ecological Applications 16:1821-1831.

Robinson, G. R., J. F. Quinn, and M. L. Stanton. 1995. Invasibility of experimental habitat islands in a California winter annual grassland. Ecology 76:786-794.

Roché, B. F. Jr, C. T. Roché, and R. C. Chapman. 1994. Impacts of grassland habitat on yellow starthistle (Centaurea solstitialis L.) invasion. Northwest Science 68:86-96.

Seabloom, E. W., W. S. Harpole, O. J. Reichman, and D. Tilman. 2003. Invasion, competitive dominance, and resource use by exotic and native California grassland species. Proceedings of the National Academy of Sciences 100:13384-13389.

Suding, K. N., D. E. Goldberg, and K. M. Hartman. 2003. Relationships among species traits: separating levels of response and identifying linkages to abundance. Ecology 84:1-14.

Thomsen, M. A., and C. M. D'Antonio. 2007. Mechanisms of resistance to invasion in a California grassland: The roles of competitor identity, resource availability and environmental gradients. Oikos 116: 17-30.

Thomsen, M. A., C. M. D'Antonio, K. B. Suttle, and W. P. Sousa. 2006. Ecological resistance, seed density and their interactions determine patterns of invasion in a California coastal grassland. Ecology Letters 9:160-170.

Tilman, D. 1997. Community invasibility, recruitment limitation, and grassland biodiversity. Ecology 78:81-92.

Vitousek, P. M., and D. U. Hooper. 1997. The effects of plant composition and diversity on ecosystem processes. Science 277:1302-1305.

Young, S. L., J. N. Barney, G. B. Kyser, T. S. Jones, and J. M. DiTomaso. 2009. Functionally similar species confer greater resistance to invasion: Implications for grassland restoration. Restoration Ecology 17: 884-892.

Young, S. L., G. B. Kyser, J. N. Barney, V. P. Claassen, and J. M. DiTomaso. 2010. Spatio-temporal relationship between water depletion and root distribution patterns of Centaurea solstitialis and two native perennials. Restoration Ecology. DOI: 10.1111/j.1526-100X.2009.00624.x

Zavaleta, E. S., and K. B. Hulvey. 2007. Realistic variation in species composition affects grassland production, resource use and invasion resistance. Plant Ecology 188:39-51. 